Жалко, Тетяна. «Метафорична вербалізація концепту “вогонь” у поетичному доробку Євгена Маланюка». Лінгвостилістичні студії, вип. 12, 2020, с. 54-61.

Zhalko, Tetiana. "Metaphorical Verbalization of the Concept Fire in the Poetic Heritage of Yevhen Malaniuk". Linguostylistic Studies, iss. 12, 2020, pp. 54-61.

УдК 81'373.612.2:82-028.16

https://doi.org/10.29038/2413-0923-2020-12-54-61

\title{
МЕТАФОРИЧНА ВЕРБАЛІЗАЦІЯ КОНЦЕПТУ «ВОГОНЬ» У ПОЕТИЧНОМУ ДОРОБКУ ЄВГЕНА МАЛАНЮКА
}

\author{
Тетяна Жалко \\ Луцький інститут розвитку людини Університету «Україна», \\ Луцьк, Україна
}

У статті досліджено метафоричну вербалізацію концепту «вогонь» у поетичному доробку Євгена Маланюка. 3'ясовано, що поетичній мові автора властива лаконічність, а стилістичні засоби репрезентують своєрідність його поетичного світобачення у процесі образного моделювання індивідуальної мовної картини світу. Наголошено, що вербальну стихію та поетичну розкутість митця реалізують метафоричні побудови. Доведено, що метафорична вербалізація концепту «вогонь» у творчому доробку $Є$. Маланюка позначає передусім негативні переживання та емоції - сум, ненависть, страждання, образу, піднесеність.

Ключові слова: метафора, концепт «вогонь», світобачення митця, індивідуалізація стилю.

\section{METAPHORICAL VERBALIZATION OF THE CONCEPT FIRE IN THE POETIC HERITAGE OF YEVHEN MALANIUK Tetiana Zhalko}

Lutsk Institute of Human Development of University Ukraine, Lutsk, Ukraine

The article focuses on the terminological system of metaphor as a key device in the system of stylistic means of Yevhen Malaniuk. The author argues that verbal power and poetic looseness of the artist are realized via metaphorical constructions, which emerge as the result of the author's creative work. The poetic language of Yevhen Malaniuk is laconic, and his stylistic devices represent the originality of the author's poetic worldview developed in the process of metaphoric modeling of the individual linguistic picture of the world. E. Malaniuk sought to embody the best qualities of the national language, choosing various linguistic means, consistent with the ideological and thematic content of the poetic works, maximizing their creative potential, preferences, and tastes, representing the richness of metaphorical devices, and accuracy in expression. The poet's individual style manifests itself in the manner of a poem, a special way of thinking, lexical-semantic and stylistic senses, searching for original means of metaphorical verbalization of the concept fire, semantics and aesthetics of the word individualization. The study has revealed that E. Malaniuk's metaphors are based on creative rethinking, artistic individual complication, and semantic transformation of the heritage of folk song and classical Ukrainian poetry of the XIX-XX centuries. The concept fire belongs to the basic models, figurative constants of the artist's poetic work. The author substantiates that the metaphorical verbalization of the concept fire in the creative work of E.

(C) Жалко Т., Східноєвропейський національний університет імені Лесі Українки, 2020.

Це стаття відкритого доступу на умовах CC BY-NC 4.0 
Malaniuk embodies the biblical symbolic meaning of God's punishment, after which a human is purified of all defilements and rises to a qualitatively higher level of spiritual development, so fire means suffering but at the same time it is liberation from the old, depressing; denoting the inner world of a person. The archetypal image of the fire actualizes the meanings associated with the destructive function of this phenomenon, so even a positive feeling of love is characterized as torment. Thus, the verbalization of the concept fire metaphorically refers primarily to negative experiences and emotions - sadness, hatred, suffering, insulting.

Key words: metaphor, concept fire, worldview of the artist, individualization of style.

Вступ. Метафора як художній засіб і складник авторської творчості здавна привертає увагу науковців, оскільки належить до найдавніших стилістичних понять. Свого часу давньогрецький філософ i логік Аристотель наголошував, що вміння складати метафори - це особливий поетичний дар. За визначенням мислителя, «складати хороші метафори означає підмічати схожість» (Банфи 113). О. Потебня називав метафору вінцем авторського мовно-творчого пошуку в створенні образу та найповнішому відображені думки. При цьому вчений наголошував, що «поетичність мови, тобто образність окремих слів і постійних словосполучень, якою б помітною вона не була, нікчемна порівняно із здатністю мов створювати образи зі сполучень слів, незалежно від того, образні вони чи ні» (Потебня 104).

На сьогодні до метафори проявляється значний теоретичний інтерес. Лінгвістика, поетика, філософія, естетика, мистецтвознавство, семіотика, логіка, когнітивна психологія, риторика досліджують метафору в різних аспектах, співставляючи ії з образом, символом. У цьому контексті вагома роль відводиться художньо-образному мисленню, яке $\epsilon$ домінантою у процесі творення метафори як медійної номінації.

Дослідженню метафори у різних аспектах їі функціонування свого часу присвятили свої наукові праці В. Телія, І. Голуб, Л.Пустовіт, Н. Артюнова, О. Глазунова та інші. Серед сучасних науковці, які досліджують насамперед світогляд певного митця 3 позиції використання процесу метафоризації, варто виокремити таких, як І. Дзюба, М. Ільницький, Г. Клочек, Л. Кравець, Т. Салига, Н. Лисенко, Ю. Войчишин, О. Астаф'єв, Ю. Ковбасенко, А. Загнітко, Л. Куценко, Т. Єщенко та інші.

Виважену інтерпретацію мови художніх творів Є. Маланюка запропонували Л. Ставицька, С. Єрмоленко, Л. Бублейник, О. Семенець, О. Тищенко.

Процес метафоризації, виступаючи одним зі способів відображення мовної картини світу, посідає чільне місце в мові загалом, а в художньому тексті метафора $\epsilon$ потужним елементом відображення поетичної структури художнього світу письменника. Аналізуючи метафоричні структури творчого доробку Євгена Маланюка, зробимо спробу дослідити особливості метафоричної вербалізації словесної номінації вогонь. 
Метою дослідження є розгляд структурних особливостей метафор, що втілюють концепти природних процесів/стихій у творчості Євгена Маланюка.

Матеріал і методи дослідження. Для визначення функцій та ролі метафор у творчості Євгена Маланюка використано відповідні методи дослідження. Зокрема, метод стилістичного експерименту застосовано для вивчення доречності вибору словесних одиниць, метод лінгвостилістичного спостереження застосовано для аналізу ролі метафоричних конструкцій у творенні словесних образів, метод концептуального аналізу спрямований на з'ясування семантики словесних образів із символічним значенням, а також на відтворення мовної особистості автора.

Результати дослідження та дискусія. Метафора - один із найпоширеніших тропів і засобів творення художньо-образної мови. Загальновизнаною у сучасній лінгвістиці $є$ думка про активізацію тропів у художній літературі XX ст., а серед них найбільше - метафори, яка $\epsilon$ потужним прийомом у передачі сприйняття й асоціативності мислення.

На сьогодні існує чимало потрактувань терміну «метафора». В академічному тлумачному словнику української мови подано таке визначення означеної дефініції: «МЕТА́ФОРА, и, жін. Художній засіб, що полягає в переносному вживанні слова або виразу на основі аналогії, схожості або порівняння, а також слово або вираз, ужиті в такий спосіб» (Словник 4: 687). Отже, в основі метафори лежить логічний принцип аналогії. У зв'язку з цим метафора вносить у мовлення найбільш конкретні предикати, які визнаються образними, завдяки чому вона дозволяє якнайточніше відтворити концепт таким, яким він уявляється авторові висловлювання. Тому метафора, особливо та, складовим елементом якої виступає ключовий у творчості поета образ, найвиразніше репрезентує світогляд митця і, відповідно, його індивідуальний стиль.

$€$. Маланюк - автор оригінальної історіософії. Його творчість примітна складною асоціативністю мислення, філософським тлумаченням навколишньої дійсності, і саме метафора $\epsilon$ тим художнім засобом, який допомагає впоратися з цим авторським завданням. Часто саме завдяки метафорі відбувається процес осмислення буття, формування світобачення у поезії Є. Маланюка. Саме метафора робить стиль автора самобутнім, оригінальним (Пустовіт).

Поетичний світ Є. Маланюка надзвичайно різноманітний, багатий на громадянські, історіософські, патріотичні та інтимні мотиви й образи. У поетичному доробку $Є$. Маланюка $\epsilon$ чимало опорних слів, які виступають підгрунтям для більш розгорнутих метафоричних образів. Ключовим серед них $\epsilon$ образ вогню, який залежно від контексту, набуває нових семантичних відтінків. Метафоричні структури, у яких домінує номінація вогонь, у поезіях Євгена Маланюка найчисленніші. Подекуди їх можна тлумачити як трансформовану архетипну метафору - «релікт універсальноколективних начал людської психіки та образ етноміфологічного канону» 
(Тимошенко 31). На думку Ю. Тимошенка така метафора «має значно вищий ступінь функціональності в художньому тексті, ніж індивідуальноконтекстуальний троп, бо вона володіє потужним сугестивним зарядом інтенцією вражати, навіювати, захоплювати» (Тимошенко 31).

За нашими спостереженнями образ вогню і всі, що належать до цієї семантичної групи (горіти, палати, палахкотіти, розгорятися, згоряти, гаснути, спалювати, випалювати, полум'я, жар, ватра, купина неопалима, пожар, пекло, жар, попіл, смолоскип, пломінний стовп тощо), у поезіях $€$. Маланюка найбільше.

Високою емоційною напругою характеризується в Є. Маланюка біблійний образ пломінного стовпа, який виступає в тексті разом з іншими реаліями зі Святого Письма, поєднуючись, наприклад, з образом пустиніневолі, звідки виходять гнані і скривджені:

Бились бурі золоті і сині,

Рокотав литавровий натовп,

Із пустинь в прозору далеч сині

Вів і заклинав пломінний стовп...

Пропалахкотіло. Промайнуло.

Пропекло навік залізні дні (Маланюк 125-126).

Особливо численні в поезії Є. Маланюка метафори - своєрідні поєднання слів вогонь, залізо, їхні семантичні поля в ідіостилі поета взаємодіють настільки тісно, що іноді перекривають одне одного. Це призводить або до їхнього ототожнення (лексеми замінюють одна одну без утрати для тексту смислової, емоційної напруженості), або до парадоксального словесного зв'язку: Епоха йде молитви і вогня [...] (Маланюк 167), I встане вік молитви і заліза (Маланюк 216), I все ж із серия виллять треба мед I полум'ям наллять його залізним (Маланюк 368), Бо незбагненно темен і димен Цей уперто тривалий час, Час залізний варягів і римлян, Час сталевий вогню і меча (Маланюк 238).

У семантиці образів, що утворюють лексико-асоціативне поле вогню, виявляється парадоксальність ідіостилю поета, яка є однією з прикметних рис «картини світу»у творчості Євгена Маланюка. Ці образи формують семантично надскладні метафоричні конструкції, що $\epsilon$ результатом взаємодії різних смислових перетворень, заснованих на символічних конотаціях. У творчості Є. Маланюка слово вогонь реалізує образність, схарактеризовану X. Керлотом: «Вогонь $\epsilon$ образом енергії, що може бути як на рівні тваринної пристрасті, так і в площині духовної сили» (352).

$€$. Маланюк специфічно втілює в образах вогню душевні переживання: у нього переважають метафори, в яких модифікатором $\epsilon$ назва негативних почуттів. Позитивні ж емоції, що подекуди прочитуються в образних сполуках, набувають загрозливої сили:

Де марна колоточ ловитви,

Горить любові ярий гнів

I хрест меча, і меч молитви (Маланюк 329). 
Порівняння гніву з вогнем виявляється через співвідносне із цією природною стихією дієслово горіти. Отже, Маланюковий образ вогню (засіб вираження стану людини), як і в народній творчості, $\epsilon$ амбівалентним: вогонь означає і життя, і смерть, і любов, і ненависть.

В «Уривку з поеми» автор метафорично висловлює свій гнів, говорячи, що «... в <...> огні Держава рухнула...». Знову ж таки вогонь стихія, яка знищує усе те, що цінне і важливе для усіх і кожного зокрема. У цьому контексті вогонь - це нищівна сила, яка спопеляє не лише автора, а й ліричного героя, котрий вболіває за державу та її незалежність від будьякого ворога.

Образ вогню - це не лише життєвий запал, пристрасність жінки, але й згуба, сутність, що спалює.

І ось над суєтою днів

Де марно колоточ ловитви,

Горить любові ярий гнів

I хрест меча, і меч молитви (Маланюк 329).

Кармен, Кармен - безодне чорна.

O, не принижуй і не ваб! [...]

На стегна, стягнуті єдвабом,

Лягла смаглявая долонь,

І в кожнім русі дише зваба,

І в кожнім відрусі - вогонь! (Маланюк 182).

Актуалізація в тексті відразу кількох значень одного слова в ускладнених метафорах Є. Маланюка - характерна риса його стилю. У подібних художніх текстах, як писав Р. Барт, «письменник помножує значення, залишаючи їх незавершеними; з допомогою мови він створює світ, перенасичений означаючими, але який так і не отримує остаточного означуваного... Коли мова стає сама для себе, тоді з'являються рухомі і плинні вторинні смисли» (Барт 284).

Складники метафоричної репрезентації лексеми вогню, поєднуючись із бурями вогню, беруть участь у творенні нового образу - воїна, бунтівника, вільної людини, яка вірить у відновлення історичної справедливості:

Цю спалену твою свободу

I напівмертвого тебе,

Народе мій, вітаю словом

Під небом, від пожеж багровим,

Під гуркоти чужих гармат... (Маланюк 421).

Цінність чуттєвого сприйняття образного зв'язку почуття з вогнем $€$. Маланюк відновлює іноді шляхом смислової компресії в метафоричній конструкції кількох фразеологізмів, т. зв. контамінації їх (Ужченко, i Авксентьєв 151): прошити серце ('викликати, спричинити у кого-небудь глибоке, гостре почуття' (Фразеологічний 2: 714), вогонь серия, серце 
горить ('хто-небудь перебуває в стані сильного збудження, хвилювання і т. ін.' (Фразеологічний 2: 792). Злиття значення цих відтворюваних за традицією мовних одиниць гіперболізує вияв напруги почуття: Вже кров жене солодке зло, Вже серце полум'ям прошило (Маланюк 263).

Якщо вогонь стійко пов'язується народною поезією з життям, то попіл у свідомості мовців асоціюється зі смертю. Лексема попіл реалізує у віршах Є. Маланюка також імпліцитно присутню у його лексикосемантичній структурі сему 'горе'. Таким чином, метафора: Здавалось, всі отрути випито I дух на попіл перетлів [...] (Маланюк 73) відображає ліричного героя вкрай спустошеним.

Такий же смисл відтворюється в дещо видозміненій розгорнутій метафорі: Що серце спить, як жертовник пустий, Бо, тліючи, на попіл перетліло (Маланюк 548).

Почуття спустошення і водночас відчаю відчувається і в таких поетичних рядках:

А той син безпритульний блукав - не забудь! -

Вулицями чужого й ворожого міста,

І в потухлій душі його був тільки попіл,

тільки попіл від неньчиних слів (Маланюк 610).

Образ вогню у Є. Маланюка - це і туга за втраченою батьківщиною, рідним краєм:

\section{А я на полум'ї розлуки}

Назавше спалюю роки,

І сниться степ Твій, сняться муки

I на узгір'ях - вітряки (Маланюк 98).

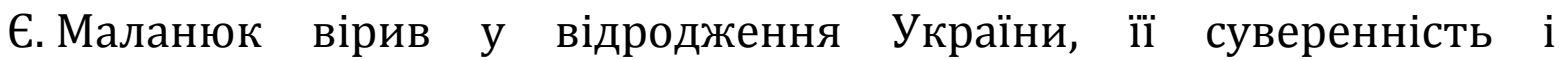
незалежність. I ці сподівання поет теж висловив за допомогою метафоричної вербалізації лексеми вогонь, розуміючи, що свобода здобувається у боротьбі:

Але недаром, о, недаром

Я креслив літери цих літ:

Мій жар спахне колись ударом,

І в дійсність обернеться міт.

Мій ярий крик, мій біль тужавий,

Випалюючи ржу і гріх,

Ввійде у складники держави,

Як криця й камінь слів моїх (Маланюк 134).

У поезії останнього вогонь наснажується насамперед громадянським, патріотичним пафосом, цей образ передає особливість стосунків ліричного героя з Батьківщиною, яка постає в іпостасі коханої жінки, - інтимну теплоту, відчуття нерозривної єдності двох пов'язаних істот.

Отже, вербалізація концепту вогонь метафорично позначає передусім внутрішній стан людини - сум, ненависть, страждання, образу, піднесеність; втілює в поезіях сутність таких значень як випробування, жертовність, 
терпіння, що інтерпретують спосіб переродження нації в самостійну й незалежну.

Висновки та перспективи дослідження. Отже, можемо стверджувати, що саме метафора $є$ тим стрижнем, що дала можливість Є. Маланюкові втілити задуми, виокремити образні домінанти, влучно висловити свої емоції та витворити власний неповторний індивідуальний стиль.

Актуальним вважаємо подальше лінгвостилістичне дослідження метафоричних конструкцій Є. Маланюка для виявлення закономірностей моделювання індивідуально-авторських стилістичних фігур, що уможливить з'ясування особливих змін у репрезентації поетичного мовомислення та світовідчуття митця.

\section{Список використаної літератури}

Банфи, Антонио. Философия искусства. Перевод с итал. Г. П. Смирнова. Москва: Искусство, 1989.

Барт, Ролан. Избранные работы: Семиотика. Поэтика. Москва: Прогресс, 1989.

Бублейник, Людмила. «Структурно-семантичні особливості “речовинних" метафор у поезіях Є. Маланюка 20-х pp. (збірки “Стилет і стилос", “Гербарій”)». Особливості художнього мовлення. Луцьк: Вежа, 2000, с. 125-134.

Бублейник, Людмила. «Образ вітру в ліриці Є. Маланюка». Особливості художнього мовлення. Луцьк: Вежа, 2000, с. 135-145.

Єрмоленко, Світлана. «Біль слова Євгена Маланюка». Нариси з української словесності (стилістика та культура мови). Київ: Довіра, 1999, с. 203-10.

Керлот, Хуан. Словарь символов. Москва: REFL-book, 1994.

Потебня, Александр. Теоретическая поэтика. Москва: Высшая школа, 1990.

Маланюк, Євген. Поезії. Львів: УПІ ім. Івана Федорова; Фенікс ЛТД, 1992.

Пустовіт, Любов. Засоби вираження метафори. URL: kulturamovy.univ.kiev.ua/KM/pdfs/ Magazine11-3.pdf.

Семенець, Олена. Організація художнього простору в поезії Є. Маланюка (гори та їх темпоритм). Українське і слов'янське мовознавство: Матеріали Міжнародної наукової конференції на честь 80-річчя професора Й. Дзендзелівського, вип. 4. Ужгород, 2001, с. 471-4.

Словник української мови, за ред. І. К. Білодіда. В 11 т. Київ: Наукова думка, 1970-1980.

Ставицька, Леся. «Образ України в поезії Євгена Маланюка». Культура слова, вип. 50, 1997 , c. 22-6.

Ставицька, Леся. Естетика слова в українській поезії 10-30рp. ХХ cm. Київ: Правда Ярославичів, 2000.

Тимошенко, Юрій. «Феномен метафори: проблема давня й сьогочасна». Слово $і$ час, № 5 , 2001, c. 29-36.

Тищенко, Оксана. Метафора у поезіях Є. Маланюка (семантико-функціональний аспект). Автореф. дис. ... канд. філол. наук: 10.02.01. Київ, 1997.

Тищенко, Оксана. «Наскрізні базові та інтродуктивні образи як виражальні засоби у структурі поетичного тексту (на прикладі метафор поезії Є. Маланюка)». Мовознавство, № 1, 2001, с. 41-5.

Ужченко, Віктор, і Авксентьєв, Леонід. Українська фразеологія. Харків: Основа, 1990.

Фразеологічний словник української мови, уклад. В. М. Білоноженко, В. О. Винник, I. С. Гнатюк та ін. У 2 кн. 2-ге вид. Київ: Наукова думка, 1999. 


\section{References}

Banfi, Antonio. Filosofija iskusstva. Translated by G. P. Smirnov. Moskva: Iskusstvo, 1989.

Barthes, Roland. Izbrannye raboty: Semiotika. Pojetika. Moskva: Progress, 1989.

Bubleinyk, Liudmyla. "Strukturno-semantychni osoblyvosti "rechovynnykh" metafor u poeziiakh Ye. Malaniuka 20-kh rr. (zbirky "Stylet i stylos", "Herbarii")". Osoblyvosti khudozhnoho movlennia. Lutsk: Vezha, 2000, pp. 125-134.

Bubleinyk, Liudmyla. "Obraz vitru v lirytsi Ye. Malaniuka". Osoblyvosti khudozhnoho movlennia. Lutsk: Vezha, 2000, pp. 135-145.

Yermolenko, Svitlana. "Bil slova Yevhena Malaniuka". Narysy z ukrainskoi slovesnosti (stylistyka ta kultura movy). Kyiv: Dovira, 1999, pp. 203-10.

Cirlot, Juan. Slovar' simvolov. Moskva: REFL-book, 1994.

Potebnja, Aleksandr. Teoreticheskaja pojetika. Moskva: Vysshaja shkola, 1990.

Malaniuk, Yevhen. Poezii. Lviv: UPI im. Ivana Fedorova; Feniks LTD, 1992.

Pustovit, Liubov. Zasoby vyrazhennia metafory. kulturamovy.univ.kiev.ua/KM/pdfs/ Magazine11-3.pdf.

Semenets, Olena. "Orhanizatsiia khudozhnoho prostoru v poezii Ye. Malaniuka (hory ta yikh temporytm)". Ukrainske i slovianske movoznavstvo: Materialy Mizhnarodnoi naukovoi konferentsii na chest 80-richchia profesora Y. Dzendzelivskoho, iss. 4. Uzhhorod, 2001, pp. 471-4.

Slovnyk ukrainskoi movy, edited by I. K. Bilodid. 11 vols. Kyiv: Naukova dumka, 1970-1980.

Stavytska, Lesia. “Obraz Ukrainy v poezii Yevhena Malaniuka”. Kultura slova, iss. 50, 1997, pp. 22-6.

Stavytska, Lesia. Estetyka slova v ukrainskii poezii 10-30 rr. XX st. Kyiv: Pravda Yaroslavychiv, 2000.

Tymoshenko, Yurii. «Fenomen metafory: problema davnia y sohochasna». Slovo i Chas / Word and Time, no. 5, 2001, pp. 29-36.

Tyshchenko, Oksana. Metafora u poeziiakh Ye. Malaniuka (semantyko-funktsionalnyi aspekt). PhD Thesis Abstract. Kyiv, 1997.

Tyshchenko, Oksana. "Naskrizni bazovi ta introduktyvni obrazy yak vyrazhalni zasoby u strukturi poetychnoho tekstu (na prykladi metafor poezii Ye. Malaniuka)". Movoznavstvo, no. 1, 2001, pp. 41-5.

Uzhchenko, Viktor, and Avksentiev, Leonid. Ukrainska frazeolohiia. Kharkiv: Osnova, 1990.

Frazeolohichnyi slovnyk ukrainskoi movy, edited by V. M. Bilonozhenko, V. O. Vynnyk, I. S. Hnatiuk ta in. 2 vols. $2^{\text {nd }}$ ed. Kyiv: Naukova dumka, 1999. 